\title{
PENERAPAN MODEL PEMBELAJARAN KOOPERATIF TIPE NHT UNTUK MELATIHKAN KETERAMPILAN METAKOGNITIF PADA MATERI ASAM BASA KELAS XI SMAN 1 WARU
}

\author{
THE IMPLEMENTATION OF COOPERATIVE LEARNING TYPE NHT TO TRAIN \\ METACOGNITIVE SKILLS ON ACID-BASE MATTER FOR \\ THE ELEVENTH GRADE OF SMAN 1 WARU
}

\author{
Siti Mahmuda dan *Utiya Azizah \\ Jurusan Kimia FMIPA Universitas Negeri Surabaya \\ e-mail: utiyaazizah@unesa.ac.id
}

\begin{abstract}
Abstrak
Penelitian ini memiliki tujuan mendeskripsikan keterlaksanaan model pembelajaran dengan model kooperatif tipe $N H T$, aktivitas peserta didik, dan melatihkan keterampilan metakognitif pada materi asam basa. Rancangan yang digunakan dalam penelitian yaitu One Group Pre-test Post-test pada kelas XI MIA 6 SMAN 1 Waru sebanyak 36 peserta didik. Hasil penelitian yang telah dilakukan menunjukkan : 1) Nilai keterlaksanaan model pembelajaran kooperatif tipe NHT pada tiap-tiap fase berturut-turut sebesar 4,00; 3,$33 ; 4,00 ; 3,89 ; 3,93$; dan 3,85 pada pertemuan pertama, pada pertemuan 2 berturut-turut sebesar 4,00; 3,56; 4,00; 4,00; 4,00; dan 4,00, pada pertemuan 3 berturut-turut sebesar 4,00;4,00;4,00;4,00;4,00; dan 3,70 , dengan kategori sangat baik. 2) Aktivitas peserta didik pada pertemuan 1, 2, dan 3 yang memiliki persentase lebih besar adalah peserta didik saat melakukan percobaan (monitoring skills) yang mempunyai persentase rata-rata sebesar 23,90\%,17,40\%, dan 18,30\% dibanding dengan aktivitas peserta didik yang lainnya. 3) Keterampilan metakognitif mengalami peningkatan yang baik memperoleh $\mathrm{N}$-gain sebesar $80,56 \%$ dengan kategori tinggi. Berdasarkan hasil penelitian dapat disimpulkan bahwa penerapan model kooperatif tipe NHT dapat melatihkan keterampilan metakognitif pada materi asam basa meningkat secara baik.
\end{abstract}

Kata kunci: NHT, keterlaksanaan, aktivitas, keterampilan metakognitif.

\begin{abstract}
This study aims to describe the implementation of learning models with NHT type cooperative models, student activities, and practice the metacognitive skills on acid-base material. The design used in the study is One Group Pre-Test Post-test in class XI MIA 6 SMAN 1 Waru as many 36 students. The results of the research that have done show: 1) The value of the implementation of the NHT type of cooperative learning model in each successive phase is 4.00; 3.33; 4.00; 3.89; 3.93; and 3.85 at the first meeting, at the 2nd meeting in a row at 4.00; 3.56;4.00; 4.00; 4.00; and 4.00, at the 3rd meeting in a row at 4.00; 4.00; 4.00; 4.00; 4.00; and 3.70, with a perfect category. 2) Student activities at meetings 1, 2, and 3 that have a Higher percentage are students when conducting experiments (monitoring skills), which have an average rate of $23.90 \%, 17.40 \%$, and $18.30 \%$ compared to the activities of other students. 3) Metacognitive skills had a good increase in N-gain of $80.56 \%$ with a high category. Based on results of the study, it could be concluded that the implementiton of NHT type cooperative model can practice metacognitive skills on acidbase material to increase correctly.
\end{abstract}

Keywords: NHT, Feasibility, Activity, Metacognitive skills.

\section{PENDAHULUAN}

Pendidikan pada saat ini menjadi hal yang sangat krusikal bagi semua aspek kehidupan, yang dimana pemerintah dan masyarakat memegang peranan yang sangat penting. Banyak perubahan yang terjadi pada sistem pendidikan guna dapat meningkatkan kualitas sumber daya manusia.
Pengembangan kualitas sumber daya manusia harus sesuai dengan kualitas pembelajaran yang diberikan selama masa pendidikan. Profil kualifikasi dalam hal kemampuan lulusan sangat diperlukan untuk standar kompetensi lulusan, dalam hal ini dapat mewujudkan peningkatan kuliatas pendidikan. Cara dalam mengolah 
pengetahuan yang ada juga dibutuhkan pengetahuan serta metakognitif, hal ini sejalan dengan Permendikbud Nomor 20 tahun 2016 menyatakan bahwa standar kompetensi lulusan yang wajib dimiliki dalam wawasan yaitu memiliki wawasan faktual, konseptual, prosedural serta metakognitif pada tingkat spesifik, detail, teknis, dan kompleks berkenaan dengan ilmu pengetahuan [1].

Hal yang menjadi dasar dalam metakognisi adalah pengetahuan yang dimiliki oleh seseorang untuk memecahkan suatu masalah dari proses berpikirnya. Metakognitif juga berperan untuk menyadari hambatan dalam memecahkan suatu permasalahan [2]. Kemampuan dalam metakognitif dibagi menjadi 2 komponen, yakni pengetahuan metakognitif dan keterampilan metakognitif [3]. Dalam hal ini, keterampilan metakognitif menjadi pokok dalam persiapan akan belajar dari suatu hal, memantau peningkatan hasil belajar, serta mengoreksi apa yang sudah dipelajari dalam memecahkan suatu masalah [4].

Keterampilan metakognitif yaitu keterampilan seseorang mengetahui serta memahami proses pembelajarnya sendiri untuk mencapai prestasi belajar sesuai yang dikehendaki. Hal tersebut diperkuat dengan argumen yang menyatakan bahwa keterampilan metakognitif adalah peserta didik berfikir untuk berfikir [5]. Melalui keterampilan metakognitif yang dimilikinya, peserta didik dapat mengontrol diri sendiri pada proses belajarnya, dengan demikian keterampilan tersebut dapat mendukung pembelajaran yang terfokus pada peserta didik. Proses pembelajaran berdasarkan kurikulum 2013, peran aktif peserta didik merupakan hal yang penting dalam proses pembelajaran.

Berdasarkan hasil angket pra penelitian yang dilaksanakan pada Hari Rabu tanggal 30 Oktober 2019 sebanyak 54,55\% peserta didik mengatakan bahwasannya salah satu dari pelajaran kimia yang dianggap sulit adalah materi asam basa. Berdasarkan hasil angket yang disebarkan sebelumnya menjelaskan bahwa keterampilan metakognitif peserta didik masih tergolong rendah dengan persentase Planning skills didik sebesar 21,87\%, Monitoring skills sebesar 42,90\%, dan Evaluating skills sebesar $43,75 \%$. Berdasarkan hasil tersebut, perlu model pembelajaran yang tepat untuk dapat melatihkan keterampilan metakognitif peserta didik pada materi asam basa.

Penerapan model kooperatif mendorong peserta didik agar saling bekerjasama dalam menyumbangkan suatu ide atau gagasan, serta bertanggung jawab sesuai hasil belajar individu ataupun kelompok yang telah dicapai berdasarkan skema belajar peserta didik. Peserta didik juga dituntut untuk dapat menemukan konsep sendiri. Adapun sintak model kooperatif antara lain menyampaikan tujuan serta memotivasi peserta didik, menyajikan informasi, membagi peserta didik kedalam kelompok belajar, membimbing kelompok bekerja serta belajar, mengevaluasi, serta memberikan reward yang terkait dengan proses berpikir peserta didik [6].

Pelatihan keterampilan metakognitif peserta didik melalui penerapan model NHT pada materi asam basa peserta didik melakukan sesuai sintaks meliputi fase 2 (menyajikan informasi) : terdapat dimensi Planning skills, peserta didik dibimbing untuk menuliskan tujuan pembelajaran, mengidentifikasi untuk mendapatkan suatu informasi penting (mengidentifikasi masalah, menentukan rumusan masalah, hipotesis, dan variabel percobaan). Fase 4 (membimbing kerja tim belajar) : Monitoring skills, peserta didik dibimbing untuk mengkonsulttasikan bahan acuan, membuat catatan penting, serta tabel. Fase 5 : Evaluating skills, peserta didik merefleksi proses pembelajaran (membuat simpulan serta menjawab soal evaluasi).

Model pembelajaran kooperatif tipe $N H T$ memberikan motivasi, saling bertanggung jawab, membantu peserta didik belajar keterampilan dasar hingga penyelesaian masalah yang kompleks dapat terselesaikan dan menemukan suatu konsep. Materi asam basa mencakup tentang sifat-sifat larutan, kekuatan asam dan basa serta perhitungan pH sesuai dengan karakteristik model pembelajaran kooperatif yang meliputi perhitungan, konsep abstrak, serta menelaah data percobaan sehingga model kooperatif tipe $N H T$ bisa digunakan pada materi asam basa. Saat mengerjakan soal hitungan diperlukan ketelitian, serta kecermatan dalam menyelesaikan soal dengan baik dan benar [7]. Peserta didik akan lebih 
mudah dalam memahami konsep yang sukar apabila peserta didik dapat mendisukusikan antara satu dengan yang lain mengenai soal tersebut [8].

\section{METODE}

Jenis penelitian yang digunakan yaitu penelitian pre-eksperimen atau eksperimen semu dengan sasaran penelitian yaitu peserta didik kelas XI MIA 6 SMAN 1 Waru. Penelitian dilakukan pada semester genap 2019-2020 selama 3 kali pertemuan yaitu tanggal 21,22 , dan 28 januari 2020. Menggunakan rancangan penelitian yakni “One Group Pre-test Post-test Design" sebagai berikut :

$$
Q_{1} \times Q_{2}
$$

Q1 : Pre-test keterampilan metakognitif (Tes awal)

X : Perlakuan, yaitu penerapan model pembelajaran kooperatif tipe $N H T$

$\mathrm{Q}_{2} \quad$ : Post-test keterampilan metakognitif (Tes akhir)

Tahapan prosedur penelitian ada 3 yakni tahap persiapan, pelaksanaan, dan akhir dari penelitian. Silabus, RPP, serta LKPD adaptasi dari Rosalinda, dan Azizah adalah perangkat pembelajaran yang digunakan [9]. Adapun instrumen penelitian yang dipakai antara lain lembar pengamatan untuk keterlaksanaan model pembelajaran, lembar pengamatan untuk aktivitas, lembar untuk inventori metakognitif, serta lembar soal pretest dan posttest. Lembar inventori metakognitif sebagai data penunjang hasil tes keterampilan metakognitif peserta didik, meliputi planning skills, monitoring skills, dan evaluating skills dimana terdiri dari 20 pernyataan positif dan pernyataan negatif. Keterampilan metakognitif peserta didik dapat dilihat dari cara peserta didik dalam memecahkan soal prestest maupun posttest keterampilan metakognitif yang dianalisis berdasarkan dimensi keterampilan metakognitif.

Untuk menganalisis keterlaksanaan model kooperatif tipe Numbered Head Together (NHT) yaitu memakai parameter penskoran. Kriteria penskoran keterlaksanaan sintak model pembelajaran tipe NHT tertera pada Tabel 1.
Tabel 1. Kriteria Skor Keterlaksanaan Model Kooperatif Tipe NHT

\begin{tabular}{cc}
\hline Skor & Kriteria \\
\hline 0 & Tidak terlaksana \\
1 & $\begin{array}{c}\text { Terlaksana tetapi tidak runtut dan } \\
\text { tidak interaktif }\end{array}$ \\
2 & Terlaksana runtut namun tidak \\
interaktif \\
3 & Terlaksana runtut dan interaktif \\
\hline
\end{tabular}

Kriteria skor yang diperoleh diubah ke bentuk nilai menggunakan rumus :

$$
\text { Nilai }=\frac{\sum \text { skor yang diperoleh }}{\sum \text { skor maksimal }} \times 4
$$

Nilai yang didapatkan dikategorikan sesuai dengan Tabel 2 berikut ini :

Tabel 2. Kriteria Nilai Keterlaksanaan Model Pembelajaran

\begin{tabular}{cc}
\hline Angka & Kategori \\
\hline $1,00-1,99$ & Kurang \\
$2,00-2,99$ & Cukup \\
$3,00-3,49$ & Baik \\
$3,50-4,00$ & Sangat baik \\
\hline
\end{tabular}

Berdasarkan kriteria tersebut keterlaksanaan model dikatakan berhasil apabila nilai $\geq 3,00$.

Aktivitas peserta didik selama pembelajaran dianalisis berdasarkan rata-rata hasil pengamatan dari 3 orang pengamat. Data yang diperoleh lalu dianalisis menggunakan rumus berikut :

$\%$ Aktivitas $=\frac{\text { frekuensi aktivitas yang muncul }}{\text { frekuensi aktivitas keseluruhan }} \times 100 \%$

Kegiatan peserta didik diyatakan terlaksana baik apabila nilai persentase aktivitas yang sesuai lebih tinggi sebesar $\geq 61 \%$ dengan kategori kuat dan sangat kuat daripada aktivitas tidak sesuai. Setiap instruksi pembelajaran secara aktif telah melibatkan peserta didik dalam penyelidikan informasi dan meningkatkan kemampuan [11].

Analisis uji keterampilan dan angket inventori metakognitif dapat dilihat berdasarkan nilai pretest maupun posttest keterampilan serta inventori metakognitif peserta didik. Hasil pada keterampilan dan inventori metakognitif peserta didik dapat dihitung menggunakan rumus : 


$$
\text { Nilai }=\frac{\text { skor yang diperoleh }}{\text { total skor maksimal }} \times 100
$$

Setelah didapatkan nilai keterampilan serta inventori metakognitif, kemudian menghitung nilai rata-rata keterampilan dan inventori metakognitif peserta didik menggunakan rumus berikut :

$$
\begin{aligned}
& \begin{array}{l}
\text { Nilai rata-rata } \\
\sum \text { semua nilai metakognitif peserta didik }
\end{array} \\
& =\frac{\Sigma \text { peserta didik }}{2}
\end{aligned}
$$

Analisis dengan persamaan $N$-gain dilakukan menggunakan nilai pretest maupun posttest keterampilan metakognitif dapat yang dapat dicari menggunakan rumus berikut :

$$
<g>=\frac{\text { Skor posttest }- \text { Skor pretest }}{100-\text { Skor pretest }}
$$

Didapatkan $N$-Gain score kemudian dimasukkan ke dalam kategori pada Tabel 3.

Tabel 3. Kriteria N-Gain

\begin{tabular}{cc}
\hline Nilai & Kriteria \\
\hline $\mathrm{g} \geq 0,7$ & Tinggi \\
$0,3 \leq \mathrm{g}<0,7$ & Sedang \\
$\mathrm{g} \leq 0,3$ & Rendah \\
\hline
\end{tabular}

Keterampilan metakognitif peserta didik dapat dilatihkan dengan model pembelajaran kooperatiftipe $N H T$ jika skor $N$-gain yang didapatkan dengan kriteria sedang sampai tinggi.

\section{HASIL DAN PEMBAHASAN}

\section{Keterlaksanaan Model Pembelajaran Kooperatif tipe $\mathrm{NHT}$}

Lembar pengamatan keterlaksanaan model pembelajaran diamati oleh 3 orang pengamat yang terdiri dari mahasiswa jurusan kimia Universitas Negeri Surabaya. Lembar pengamatan keterlaksanaan model pembelajaran bertujuan untuk mengetahui tingkat keterlaksanaan model pembelajaran kooperatif tipe $N H T$ apakah telah sinkron dengan tahapan atau sintaks dalam model pembelajaran pada RPP. Keterampilan yang dimiliki guru dalam pengelolahan kelas serta KBM pada tiga kali pertemuan ini dianalisis dengan memakai instrumen lembar pengamatan keterlaksanaan model pembelajaran kooperatif tipe NHT yang telah ditelaah dan divalidasi. Model pembelajaran ini terdapat 6 fase [6]. Berikut ini merupakan diagram hasil dari pengamatan keterlaksanaan model pembelajaran kooperatif tipe NHT.

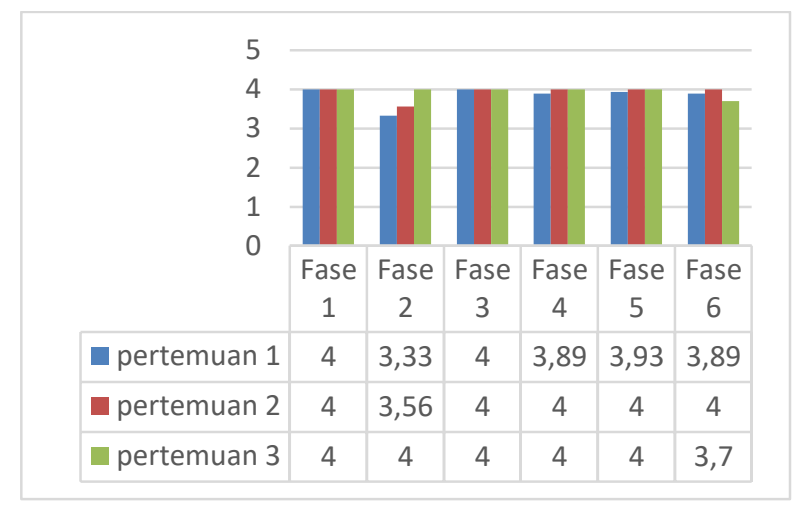

Gambar 1. Nilai Keterlaksanaan Fase Model Pembelajaran Kooperatif Tipe NHT Pada 3 Kali Pertemuan.

Gambar 1, menunujukkan bahwa guru mampu menjalankan setiap fase model pembelajaran tersebut. Disisi lain, keterampilan metakognitif peserta didik bisa diterapkan atau dilatihkan dengan model pembelajaran kooperatif tipe $N H T$.

Fase 1 menyampaikan tujuan dan memotivasi disampaikan ke peserta didik dilaksanakan sebanyak 3 kali pertemuan dimana masing-masing mendapat nilai sebesar 4,00 dan termasuk kategori sangat baik.

Fase 2 yaitu Menyajikan informasi memperoleh nilai pada 3 pertemuan sebesar 3,33; 3,56; dan 4,00 dengan kategori sangat baik. Fase ini guru juga dapat membantu peserta didik untuk menemukan fakta, prinsip, serta konsep dengan sendirinya, dan peserta didik dapat sadar dengan sendirinya akan strategi belajarnya, guru tidak hanya sekedar memberi pengetahuan saja [13]. Jadi pada fase ini guru tidak hanya memberikan penjelasan terkait sub materi saja, namun juga dapat mengasah rasa keingin tahuan peserta didik untuk dapat mengetahui konsep secara utuh dan dapat memahami siasat belajar mana yang sesuai.

Membagi peserta didik kedalam kelompok-kelompok belajar merupakan fase 3, dimana memperoleh nilai pada 3 pertemuan masing-masing sebesar 4,00 dengan mendapatkan kategori sangat baik. Memberikan nomor (Numbering) merupakan langkah awal dalam proses pembelajaran kooperatif tipe NHT [14]. Peserta didik terbagi dalam kelompok memperoleh nomor lalu digunakan dikepalanya, hal ini 
dilakukan sesuai dengan tahapan pembelajaran kooperatif tipe $N H T$.

Membimbing kerja tim belajar merupakan fase ke-4 dengan memperoleh nilai pada 3 pertemuan masing-masing sebesar 3,89; 4,00; dan 4,00 dan termasuk dalam kategori sangat baik. Pada fase ini terdapat langkah ke-2 dan langkah ke3 dari pembelajaran kooperatif tipe $N H T$ adalah mengajukan pertanyaan dan berpikir bersama. Dilatihkannya keterampilan metakognitif melalui LKPD planning skills berdasarkan indikator mengidentifikasi sehingga memperoleh informasi yang penting. Selain itu monitoring skills juga dilatihkan berdasar indikator mengkonsultasikan bahan acuan atau bahan referensi, serta membuat catatan penting dan tabel.

Fase 5 adalah mengevaluasi dengan memperoleh nilai pada 3 pertemuan masingmasing sebesar 3,93; 4,00; dan 4,00 mendapat kategori sangat baik. Tahapan-tahapan yang memuat pembelajaran $N H T$ pada fase ini adalah menjawab. Pada tahap ini, peserta didik beserta kelompoknya diminta untuk memberikan statement atau sebuah alasan berdasarkan kesimpulan yang telah disetujui lalu mendemonstrasikan hasil diskusi, serta menyelesaikan soal evaluasi secara personal yang memiliki tujuan untuk merefleksi terhadap pembelajaran untuk dilatihkannya evaluating skills.

Memberikan reward (penghargaan) merupakan fase terakhir yaitu fase ke-6 memperoleh nilai pada 3 pertemuan masingmasing sebesar 3,89; 4,00; dan 3,70 dengan predikat sangat baik. Pada proses pembelajaran berlangsung, guru memberi latihan mengenai wawasan metakognitif peserta didik pada keterampilan evaluating skills sesuai dengan indikator refleksi yang ada.

\section{Aktivitas Peserta Didik}

Selama proses pembelajaran berlangsung aktivitas peserta didik dapat kita amati. Aktivitas ini diamati 3 pengamat yang terdiri dari mahasiswa jurusan pendidikan kimia Unesa. Setiap pengamat mengamati 2 kelompok yang beranggotakan 6 peserta didik. Aktivitas peserta didik yang diamati yaitu aktivitas yang dominan muncul setiap 2 menit sekali selama 90 menit proses pembelajaran.
Berikut ini adalah hasil pengamatan aktivitas peserta didik dilihat pada Tabel 4 dibawah ini :

Tabel 4. Data Hasil Pengamatan Aktivitas Peserta Didik

\begin{tabular}{|c|c|c|c|}
\hline \multirow[t]{2}{*}{ Aktivitas Peserta Didik } & \multicolumn{3}{|c|}{$\begin{array}{c}\text { Rata-rata } \\
\text { persentase }(\%)\end{array}$} \\
\hline & P1 & P2 & $\mathbf{P 3}$ \\
\hline $\begin{array}{lr}\text { Memperhatikan } & \text { dan } \\
\text { mendengarkan } & \text { penjelasan } \\
\text { guru } & \end{array}$ & 14,4 & 15,5 & 15,6 \\
\hline $\begin{array}{l}\text { Memperhatikan dan } \\
\text { menulis informasi penting } \\
\text { mengenai sub materi } \\
\text { melalui media powerpoint } \\
\text { "Planning Skills" }\end{array}$ & 4,94 & 5,62 & 5,68 \\
\hline $\begin{array}{l}\text { Mengajukan/menjawab } \\
\text { pertanyaan }\end{array}$ & 0,62 & 0,99 & 0,99 \\
\hline Membaca fenomena LKPD & 4,2 & 3,83 & 3,7 \\
\hline $\begin{array}{l}\text { Merumuskan masalah dari } \\
\text { LKPD "Planning Skills" }\end{array}$ & 4,51 & 6,3 & 6,54 \\
\hline $\begin{array}{l}\text { Merumuskan hipotesis } \\
\text { "Planning Skills" }\end{array}$ & 5,74 & 4,81 & 4,81 \\
\hline $\begin{array}{l}\text { Menuliskan variabel dalam } \\
\text { LKPD "Planning Skills" }\end{array}$ & 2,96 & 2,96 & 2,22 \\
\hline $\begin{array}{l}\text { Menyiapkan alat dan bahan } \\
\text { yang diperlukan dalam } \\
\text { LKPD "Monitoring Skills" }\end{array}$ & 2,22 & 2,53 & 2,53 \\
\hline $\begin{array}{l}\text { Melakukan percobaan } \\
\text { "Monitoring Skills" }\end{array}$ & 23,9 & 17,4 & 18,7 \\
\hline $\begin{array}{l}\text { Diskusi bersama teman } \\
\text { sekelompok }\end{array}$ & 2,22 & 4,32 & 3,21 \\
\hline $\begin{array}{l}\text { Mengumpulkan data hasil } \\
\text { percobaan "Monitoring } \\
\text { Skills" }\end{array}$ & 3,09 & 3,09 & 3,83 \\
\hline $\begin{array}{l}\text { Mencatat jika } \\
\text { hasil diskusi } \\
\text { dianggap benar }\end{array}$ & 0,74 & 0,74 & 0,12 \\
\hline $\begin{array}{l}\text { Mengerjakan analisis data } \\
\text { yang ada di LKPD secara } \\
\text { berkelompok "Evaluating } \\
\text { Skills" }\end{array}$ & 8,15 & 6,73 & 7,1 \\
\hline $\begin{array}{l}\text { Mengerjakan soal evaluasi } \\
\text { pada LKPD " secara } \\
\text { individu "Evaluating } \\
\text { Skills" }\end{array}$ & 17,3 & 19,4 & 19,5 \\
\hline Presentasi di depan kelas & 4,01 & 4,14 & 4,32 \\
\hline $\begin{array}{l}\text { Membuat simpulan } \\
\text { pembelajaran hari ini }\end{array}$ & 0,49 & 0,62 & 0,49 \\
\hline $\begin{array}{l}\text { Melakukan kegiatan lain } \\
\text { yang tidak sesuai dengan } \\
\text { kegiatan belajar mengajar }\end{array}$ & 0,51 & 1,02 & 0,66 \\
\hline
\end{tabular}

Keterampilan metakognitif peserta didik dapat diasah melalui fase-fase yang ada pada pembelajaran kooperatif tipe $N H T$ yang terdapat didalam RPP dan LKPD yang disesuaikan dengan dimensi keterampilan metakognitif. Mengidentifikasi untuk mendapatkan informasi 
penting merupakan keterampilan metakognitif Planning skills yang dapat dilatihkan pada peserta didik. Membuat catatan penting dan tabel serta mendiskusikan bahan referensi merupakan keterampilan yang dilatihkan berdasarkan pada keterampilan metakognitif Monitoring skills. Merefleksi proses pembelajaran, dan menjawab latihan soal evaluasi yang ada di dalam LKPD merupakan keterampilan metakognitif Evaluating skills.

Kegiatan memperhatikan penjelasan guru, menulis informasi penting yang disampaikan guru, serta peserta didik menjawab atau mengajukan pertanyaan terdapat pada langkah apresiasi. Pada langkah ini guru mengaitkan sub materi asam basa terutama pada sifat-sifat larutan asam basa, kekuatan asam dan basa.

Kegiatan peserta didik membaca dan memahami permasalahan pada LKPD dilakukan pada indikator 1 yaitu Planning skills. Fenomena pada LKPD 1 berkaitan dengan sifat-sifat larutan asam basa menggunakan 2 macam indikator alami pada kertas lakmus. LKPD 2 berkaitan dengan kekuatan asam yang terdiri dari beberapa larutan asam yang diuji menggunakan kertas indikator universal. LKPD 3 berkaitan dengan kekuatan basa yang terdapat 5 macam larutan basa yang diuji menggunakan kertas indikator universal. Kegiatan merumuskan masalah, hipotesis, dan variabel pada LKPD dilakukan secara berdiskusi dengan kelompoknya untuk menentukan jawaban yang sesuai dengan pertanyaan yang ada pada LKPD.

Kegiatan mempersiapkan alat dan bahan, melakukan percobaan, serta mengumpulkan data hasil percobaan peserta didik dilatih untuk keterampilan metakognitifnya dengan cara mengkonsultasikan bahan referensi kepada guru sebelum melakukan percobaan. Setelah itu peserta didik berdiskusi dengan teman sekelompoknya untuk membuat catatan penting atau tabel hasil pengamatan percobaan pada LKPD yang sesuai pada indikator 2 yaitu Monitoring skills.

Peserta didik mengerjakan analisis data secara berkelompok, mengerjakan soal evaluasi secara individu pada LKPD, mempresentasikan hasil didepan kelas, dan membenarkan jawaban jika hasil diskusi kelas dianggap benar oleh peserta didik. Peserta didik juga membuat simpulan yang dibimbing oleh guru untuk merefleksikan proses pembelajaran yang telah dilakukan pada indikator 3 yaitu Evaluating skills. Tujuan dari merefleksikan proses pembelajaran adalah guru dapat mengecek seberapa jauh pemahaman peserta didik pada materi yang telah diajarkankan.

Kegiatan penutupan pembelajaran yang meliputi guru memberikan reward kepada peserta didik yang mendapat poin terbanyak, serta peserta didik diarahkan untuk mempelajari materi selanjutnya. Persentase aktivitas yang tidak sesuai lebih rendah dibandingkan aktivitas yang sesuai hal ini dapat dilihat berdasarkan 3 pertemuan secara berurutan sebesar 99,49\%, 98,98\%, dan 99,34\% pada Tabel 4 diatas.

\section{Keterampilan Metakognitif}

Metakognitif adalah berpikir tentang berpikir atau kognisi tentang kognisi seseorang yang bertujuan untuk meningkatkan belajar dan menyelesaikan suatu masalah [15]. Keterampilan metakognitif adalah keterampilan yang mengolah pikiran seseorang dengan baik untuk menggunakan pengetahuannya yang telah dimilikinya, merefleksi serta mengontrol proses dan hasil dari pemikirannya itu sendiri [16].

Keterampilan metakognitif terdiri dari 3 komponen yaitu planning, monitoring, dan evaluating skills [17]. Kegiatan peserta didik dalam keterampilan metakognitif meliputi menguraikan dan mengekstrak informasi utama dari pertanyaan ke dalam formulir yang dapat dipahami (misalnya, menggambar diagram dan memberi label), lalu peserta didik dapat memindai pengetahuan yang ada dengan benar (misalnya menulis rumus, peserta didik mengatur langkah-langkah yang ditunjukkan dalam menyelesaikan masalah dengan jelas dan dapat dimengerti, dan peserta didik melakukan revisi atau mengoreksi ulang apa yang diidentifikasi (misalnya mencoret jawaban dan merubah strategi), Jawaban akhir yang diberikan akurat dengan justifikasi [18].

Tercapainya hasil belajar kognitif erat kaitannya dengan kemandirian peserta didik dalam belajar, hal tersebut juga erat kaitannya dengan keterampilan metakognitif yang dimiliki peserta didik [19]. 
Berikut ini adalah data hasil keterampilan metakognitif pada setiap indikator yang didapatkan dari nilai prestest dan posttest dengan didukung angket inventori metakognitif yang diberikan pada saat pretest dan posttest sebagai data penunjang dapat ditunjukkan pada Tabel 5.

Tabel 5. Data Nilai Rata-Rata Keterampilan Metakognitif Setiap Indikator

\begin{tabular}{llll}
\hline $\begin{array}{c}\text { Indikator } \\
\text { Keterampilan } \\
\text { Metakognitif }\end{array}$ & Pretest & Posttest & N-gain \\
\hline Planning skills & 29,86 & 91,11 & 0,87 \\
Monitoring skills & 8,33 & 68,19 & 0,65 \\
Evaluating skills & 0,56 & 84,44 & 0,84 \\
\hline
\end{tabular}

Dapat dilihat dari Tabel 4, diketahui bahwa dengan dilakukannya penerapan model pembelajaran kooperatif tipe $N H T$ memperoleh $N$ gain score yang diperoleh dari 3 indikator keterampilan metakognitif mendapatkan kategori tinggi dan sedang. Hal ini membuktikan bahwa 3 indikator tesebut berhasil dilatihkannya model pembelajaran kooperatif tipe $N H T$. Namun terlihat pada indikator monitoring skills memiliki $N$-gain paling rendah dibanding 2 indikator lainnya, dikarenakan peserta didik kurang menegement waktu, hanya ada beberapa yang masih kurang memahami materi.

Ketuntasan klasikal keterampilan metakognitif sebesar 97,22\% dengan kategori tinggi dan sedang, diperoleh nilai peserta didik $\geq 75$ sebagai batas ketuntasan. Hal ini menunjukkan bahwa rata-rata peserta didik kelas XI MIA 6 memperoleh nilai diatas KKM. Sehingga menjelaskan bahwa pembelajaran kooperatif tipe NHT mampu melatihkan keterampilan metakognitif dengan perbandingan peserta didik yang tuntas lebih besar daripada peserta didik yang tidak tuntas. Sebegaimana hal ini sesuai dengan beberapa penelitian terdahulu bahwa pembelajaraan kooperatif tipe $N H T$ mampu melatihkan keterampilan metakognitif dengan baik [20]. Berikut ini merupakan uraian secara ringkas 3 indikator keterampilan metakognitif yang dilatihkan :

\section{Planning Skills}

Indikator planning skills (merencanakan) yaitu peserta didik dengan bertanya kepada diri sendiri informasi apa saja yang didapatkan berdasarkan soal yang disediakan serta waktu yang diperlukan untuk memecahkan soal tersebut [17]. Jika peserta didik sudah memahami informasi penting yang terdapat pada soal seperti konsentrasi larutan, hasil uji warna pada larutan, dan indikator apa saja yang diperlukan untuk mengetahui $\mathrm{pH}$ larutan maka peserta didik mudah untuk memilih siasat dalam memecahkan soal tersebut. Dengan ini dapat dilihat berdasarkan jawaban peserta didik dibawah ini :

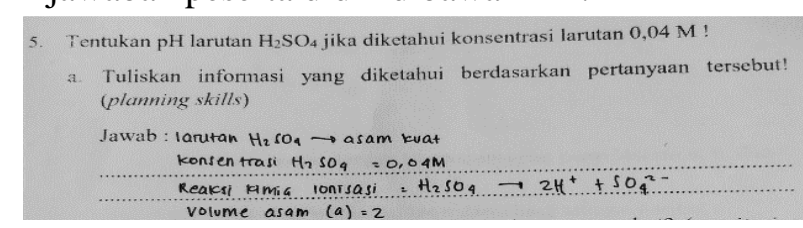

Gambar 2. Jawaban Peserta Didik Pada Tahap "Planning Skills"

Dari gambar 2, peserta didik sudah mampu menentukan informasi apa saja yang ada pada soal seperti menyebutkan larutan, menentukan konsentrasi, valensi, serta reaksi sehingga memperoleh skor 4. Bukan hanya itu saja, peserta didik juga sudah mampu memanage waktu pengerjaan untuk kegiatan keterampilan metakognitif yang lainnya. Dibuktikan pada Tabel 5 , hasil rata-rata pretest dan posttest mengalami kenaikan dengan $\mathrm{N}$-gain score sebesar 0,873 mendapatkan kategori tinggi.

\section{Monitoring Skills}

Peserta didik mengetahui apa yang akan dilakukan untuk menyelesaikan masalah derngan cara mengingat informasi yang sebelumnya diterima [17]. Setelah peserta didik mengetahui informasi penting pada soal, peserta didik dapat mengambil tindakan atau tahapan lebih lanjut supaya dapat mengerjakan soal dengan baik. Peserta didik dituntut untuk dapat menentukan $\mathrm{pH}$ larutan yang tepat seperti dibawah ini :

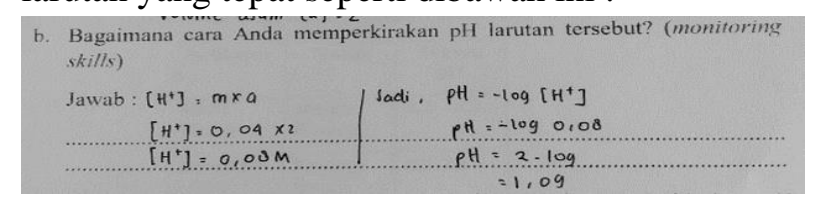

Gambar 3. Jawaban Peserta Didik Pada Tahap "Monitoring Skills"

Gambar 3 menunjukkan bahwa peserta didik dapat mengerjakan soal dengan menggunakan cara yang benar dan tepat. Hal tersebut menunjukkan bahwa peserta didik sudah 
mampu mengambil tindakan atau mempertimbangkan cara bagaimana untuk memecahkan soal tersebut. Pada Tabel 5, mengungkapkan bahwa hasil rata-rata pretest dan posttest mengalami kenaikan dengan $\mathrm{N}$-gain score sebesar 0,653 yang memiliki kriteria sedang.

\section{Evaluating Skills}

Indikator evaluating skills (mengevaluasi) merupakan kemampuan peserta didik dalam memahami seberapa baik mereka menyelesaikan sebuah persoalan sebuah [17]. Dapat kita lihat dibawah ini adalah jawaban perserta didik yang memperoleh skor 4 :

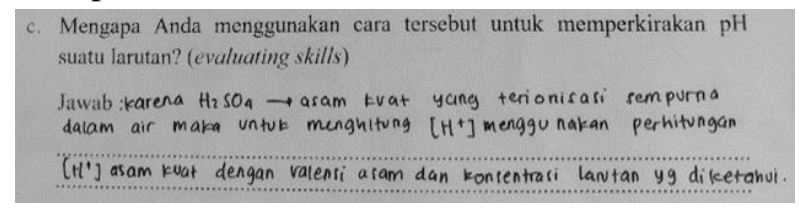

Gambar 4. Jawaban Peserta Didik Pada Tahap "Evaluating Skills"

Pada Gambar 4 diatas, dilihat bahwa peserta didik melakukan evaluasi terhadap apa yang ketahui dengan tahapan yang sesuai untuk mengerjakan soal tersebut. Membuktikan bahwa peserta didik mampu menyelesaikan persoalan. Hasil ini selaras dengan penelitian terdahulu mengungkapkan bahwa peserta didik dapat merefleksi strategi belajarnya [21]. Dibuktikan pada Tabel 5, mendapatkan hasil rata-rata pretest dan posttest sebesar 0,844 dengan kategori tinggi berdasarkan $\mathrm{N}$-gain score.

Setelah dilatihkan penerapan model pembelajaran NHT kepada peserta didik, peserta didik mengalami peningkatan keterampilan belajar asam basa. Secara klasikal, keterampilan metakognitif peserta didik pada dimensi planning skills, dan evaluating skills berada pada kategori sangat baik, sedangkan dimensi monitoring skills berada pada kategori baik. Peningkatan belajar pada peserta didik menunjukkan bahwa peserta didik dapat memahami dari tiap-tiap dimensi keterampilan metakognitif. Sehingga hasil penelitian ini sesuai dengan penelitian sebelumnya bahwa keterampilan metakognitif yang telah diberikan termasuk kategori sangat baik [22].

Nilai indeks $N$-gain untuk menentukan peningkatan keterampilan metakognitif peserta didik secara individu. Melakukan uji normalitas terlebih dahulu berdasarkan nilai pretest dan posttest menentukan nilai indeks $\mathrm{N}$-gain. Angket inventori metakognitif juga digunakan untuk meningkatkan keterampilan metakognitif dimana peserta didik sebagai responden. Dibawah ini ditunjukkan data nilai rata-rata inventori metakognitif sebagai data yang menunjang keterampilan metakognitif :

Tabel 6. Data Nilai Rata-Rata Inventori Metakognitif Peserta Didik

\begin{tabular}{|c|c|c|c|c|c|}
\hline \multirow[t]{2}{*}{ Hasil } & \multicolumn{3}{|c|}{$\begin{array}{l}\text { Keterampilan } \\
\text { metakognitif }\end{array}$} & \multirow{2}{*}{$\begin{array}{l}\text { Rata- } \\
\text { Rata }\end{array}$} & \multirow{2}{*}{$\begin{array}{l}\text { Ka- } \\
\text { teg- } \\
\text { ori }\end{array}$} \\
\hline & $\mathbf{P}$ & M & $\mathbf{E}$ & & \\
\hline & 63,39 & 63,79 & 61,23 & 62 , & Baik \\
\hline Posttest & 70,04 & 69,05 & 67,94 & 69,01 & Baik \\
\hline
\end{tabular}

Dari tabel 6, hasil rata-rata inventori metakognitif peserta didik menunjukkan bahwa terdapat kenaikan hasil belajar peserta didik setelah dilatihkannya keterampilan metakognitif. Hal yang mendukung keterampilan metakognitif yaitu planning, monitoring, dan evaluating skills.

\section{Hasil Belajar}

Hasil belajar merupakan kemampuan yang dimiliki peserta didik setelah menerima pengalaman belajar [10]. Hasil belajar peserta didik setelah diterapkan pada pembelajaran kooperatif tipe NHT untuk melatihkan keterampilan metakognitif peserta didik dikatakan berhasil yaitu hasil belajar peserta didik yang tuntas lebih tinggi dibandingkan yang tidak tuntas. Sebanyak 35 peserta didik di kelas XI MIA 6 dikatakan tuntas dengan memperoleh nilai $\geq 75$ sesuai dengan KKM di SMAN 1 Waru. Ketuntasan klasikal hasil belajar aspek pengetahuan sebesar 97\%. Artinya persentase $97 \%$ peserta didik tuntas dalam pembelajaran materi asam basa yang meliputi sifat-sifat larutan asam basa, kekuatan asam dan basa. Temuan tersebut memperkuat hasil penelitian terdahulu yang mengungkapkan bahwa terdapat hubungan yang signifikan antara keterampilan metakognitif yang baik dengan hasil belajar sehingga dapat meningkatkan hasil belajar peserta didik [23]. Hal tersebut membuktikan bahwa dalam menerapkan model pembelajaran kooperatif tipe NHT dapat melatihkan keterampilan metakognitif peserta didik dalam proses pembelajaran ditunjukkan dengan meningkatnya hasil belajar. 


\section{SIMPULAN DAN SARAN}

Berdasarkan hasil dan pembahasan dapatlah disimpulkan bahwa: (1) Hasil keterlaksanaan model pembelajaran kooperatif tipe NHT pada 3 pertemuan pada fase 1, 2, 3, 4, 5, dan 6 memperoleh nilai sebesar pada pertemuan pertama 4,$00 ; 3,33 ; 4,00 ; 3,89 ; 4,00 ; 3,85$. Pertemuan kedua sebesar 4,00; 3,56; 4,00; 4,00; 4,$00 ; 4,00$. Pertemuan ketiga sebesar 4,00; 4,00; 4,$00 ; 4,00 ; 4,00 ; 3,70$, dengan kategori sangat baik. (2) Aktivitas peserta didik yang sesuai dengan proses pembelajaran mendapatkan persentase di 3 pertemuan, yaitu masing-masing sebesar 99,49\%; 98,98\%; 99,34\%. Aktivitas peserta didik yang paling terlihat di pertemuan 1 , 2, dan 3 yaitu peserta didik secara individu (monitoring skills) mengerjakan soal evaluasi memiliki rata-rata sebesar 17,3\%, 19,4\%, dan 19,5\%. (3) Keterampilan metakognitif terjadi suatu peningkatan secara baik hal ini dapat dilihat dari 29 peserta didik memperoleh $\mathrm{N}$-gain dengan kategori tinggi. (4) Ketuntasan hasil belajar peserta didik di kelas XI MIA 6 SMAN 1 Waru mengalami peningkatan persentase ketuntasan dari $0 \%$ menjadi $97 \%$.

Saran bagi peneliti selanjutnya yaitu sebaiknya keterampilan metakognitif terus dilatihkan sejak dini agar peserta didik selalu memikirkan serta mempertimbangkan bagaimana cara mereka dalam memecahkan suatu permasalahan (planning skills), dengan menggunakan strategi yang benar (monitoring skills), dan dapat melakukan evaluasi dari penyelesaian masalah tersebut (evaluating skills), serta keterampilan metakognitif ini harus dilakukan secara rutin meskipun memerlukan jangka waktu yang relative lama dan konsisten. Peneliti juga harus telaten dalam melatihkan keterampilan metakognitif pada peserta didik.

\section{DAFTAR PUSTAKA}

1 Permendikbud Nomor 20 Tahun 2016 Tentang Standar Kompetensi Lulusan Pendidikan Dasar dan Menengah.
2 Reynolds, W. M. dan Miller, G. E. 2003. Handbook of Psychology. Educational Psychology, Vol. 7.

3 Schraw, G. \& Dennison, R.S. 1994. Assessing Metacognitive Awareness. Contemporary Educational Psychology, Vol. 19, Hal 460-475.

4 Azizah, U., dan Nasrudin, H. 2018. Empowerment of Metacognitive Skills Through Development of Instructional Materials on The Topic of Hydrolysis and Buffer Solutions. The 2nd International Joint Conference on Science and Technology (IJCST) Journal of Physics: Conf. ser. 953 012199. DOI : $\quad$ D.1088/17426596/953/1/012199.

5 Sindhawani, A. \& Sharma, M. K. 2009. Metacognitive Learning Skills. India: Educationia Confab.

6 Arends, R. L. 2008. Learning to Teach. Yogyakarta: Pustaka Belajar.

7 Nafila, E., dan Azizah, U. 2015. Keterampilan Metakognitif Siswa Melalui Model Pembelajaran Kooperatif Tipe NHT pada Materi Kesetimbangan Kimia di Kelas XI SMAN 1 Sumenep. Journal of Chemical Education, Vol. 4, No. 2, Hal 204-211.

8 Slavin, R. E. 2010. Instruction Based on Cooperative Learning. in $R$ Mayer and $P$ Alexander (Eds), Handbook of Research on Learning and Instruction. London: Taylor \& Francis.

9 Rosalinda, E., dan Azizah, U. 2017. Penerapan Model Pembelajaran Kooperatif Tipe Numbered Head Together (NHT) Untuk Meningkatkan Keterampilan Metakognitif Siswa Pada Materi Asam Basa Di Kelas XI. UNESA Journal of Chemical Education, Vol. 6, No. 3, Hal 440-445.

10 Sudjana, N. 2005. Penilaian Hasil Proses Belajar Mengajar. Bandung: PT. Remaja Rosdakarya. 
11 Vong, S. A. \& Kaewurai, W. 2017. Instructional Model Development to Enhance Critical Thinking and Critical Thinking Teaching Ability of Trainee Students At Regional Teaching Training Center in Takeo Province Camcodia. Kasetsart Journal of Social Science, Vol. 38, Hal 88-95.

12 Hake, R. 1998. Interactive-engagement Versus Traditional Methods : a Six ThousandStudent Survey of Mechanics Test Data For Introductory Physic Courses. Journal Phys, Vol. 66, Hal 97-99.

13 Nur. 2000. Pembelajaran Kooperatif. Surabaya: Unesa Press.

14 Suprijono, A. 2009. Cooperative Learning : Teori dan Aplikasi Paikem. Yogyakarta: Pustaka Pelajar.

15 Wilson, D. \& Conyers M. 2016. Teaching Student to Drive Their Brains: Metacognitive Strategies, Activities, and Lesson Ideas. New York: Eastern Suffolk BOCES.

16 Pulmones, R. 2010. Learning Chemistry in a Metacognitive Environment From St. Scolastica's College, Vol. 16, Hal 170.

17 The Teaching Excellence in Adult Literacy. 2012. Metacognitive Process. American Institutes for Research.

18 Abdullah A.H, Rahman S.N., Hamzah M.H.
2017. Metacognitive Skills of Malaysian Students in Non-Routine Mathematical Problem Solving. Bolema, Rio Claro (SP), Vol. 31, No. 57, Hal. 310 - 322.

19 Flavell, J. H. 1979. Metacognitive and Cognitive Monitoring. American Psychological Association, Inc Stanford University.

20 Yostanti, D. M., dan Azizah, U. 2016. Penerapan Model Pembelajaran Kooperatif Tipe NHT Untuk Melatihkan Keterampilan Metakognitif Materi Laju Reaksi Kelas XI Di SMAN 3 Tuban. Unesa Journal of Chemical Education, Vol. 5, No. 2, Hal 278-285.

21 Rosa, D. D. dan Azizah, U. 2017. Implementation of Learning Cycle 7E Model to Practice Metacognitive Skills on Reaction Rate Matter. Journal of Chemistry Education Research, Vol. 01, No. 1, Hal 37-43.

22 Muminin, S. K. F., dan Azizah, U. 2014. Keterampilan Metakognitif Siswa melalui Model Pembelajaran Inkuiri pada Materi Asam Basa di SMAN 1 Pacet Kelas XI. Unesa Journal of Chemical Education, Vol. 3, No. 02, Hal 67-74.

23 Nuryana, E. dan Bambang, S. 2012. Hubungan Keterampilan Metakognisi dengan Hasil Belajar Siswa. Jurnal pada pendidikan kimia FMIPA UNESA Surabaya. 